\title{
Assessment of the Effect of Technological Innovations on Unemployment in the European Union Countries
}

\section{Zigmas Lydeka, Akvile Karaliute*}

\author{
Vytautas Magnus University \\ K. Donelaicio st. 58, LT-44248 Kaunas, Lithuania \\ E-mail.zigmas.lydeka@vdu.lt; akvile.karaliute@vdu.lt \\ * Corresponding author \\ cross $^{\text {ref }}$ http://dx.doi.org/10.5755/j01.ee.32.2.24400
}

\begin{abstract}
Innovation and unemployment are two economic elements related to each other that have been constantly analyzed in the economic debates from the beginning of the 21st century. A classical question is whether innovation creates or destroys jobs. The conventional approach contemplates innovation as a transformation instrument of an economy, resulting in economic growth and jobs creation. Another approach points out to various mechanisms which can compensate the primary effect of innovations and cause an ultimate effect of innovations on labour demand to be unclear. In view of the fact that there are many different explanations about the impact of innovations on labour demand, this paper, after the analysis of theoretical and empirical scientific literature in this field, provides an empirical analysis with unemployment as the dependent variable. The authors use data from 28 European Union countries for the period of 1992-2016 and pursue to research how technological innovations affect unemployment rate. There are two core independent variables - expenditure on $R \& D$ (research and development) and number of patent applications - as the main proxies for technological innovations. Control variables that affect unemployment are included to the model as well. The model was estimated using a dynamic two-step System Generalized Method of Moments (GMM-SYS) of a panel data system. After the composition of 12 different estimations of the model, the results suggest that, in some cases, technological innovations affect unemployment.
\end{abstract}

Keywords: Technological Change; Technological Innovations; Product Innovations; Process Innovations; Unemployment.

\section{Introduction}

For more than two centuries new technologies give a positive impulse to the global economy. Each new wave of technologies stimulates economic growth, creates favorable conditions for the development of new business ideas and increases productivity. New technologies can be described as a driving force of globalization.

A question about destruction or creation of jobs, caused by technological advances, has been analyzed even by classical economists. For a long time the fear that new technologies could reduce the number of workplaces has been relevant in public policy. The main explanation of this fear is that the impact of innovations on labour market is unclear. Some compensatory effects which are able to offset the primary impact of innovations and cause an ultimate effect to be uncertain exist (Piva \& Vivarelli, 2005).

The relevance of topic of the effect of technological innovations on the labour market is based on the problems, faced by the labour market in the course of technological changes, leading to the manifestations of a new industrial revolution. The researchers describe the impact of innovations on employment, unemployment, labour demand, wages and other labour market parameters in many ways. Empirical researches in this field can be divided according to the level of analysis: macro, sectoral and micro level. It should be noted that most recent empirical researches analyzing the link between innovation and labour market parameters assess the micro level effect and there are relatively few researches on the macro level. Also, it is worth mentioning that macro level researches provide ambiguous results about the impact of innovation on (un)employment.

The object of the research: the impact of technological innovations on unemployment.

The aim of this research: to assess the effect of technological innovations on unemployment. It should be noted that, in order to assess this effect, a unique dataset, which covers 25 years period (1992-2016) and 28 European Union countries is analyzed.

The problem of the research: how do technological innovations affect unemployment?

Research methods: literature review, two-step System Generalized Method of Moments (GMM-SYS).

This paper has three main novelties. First, the paper examines research at macro level (it is rare in the field of the analyzed phenomena). Second, the paper analyzes the effect of both the number of patent applications per million population (a measure of process innovations) and expenditure on R\&D (a measure of product innovations) on unemployment (it is rare in the scientific literature). Third, this research uses a modified form of the standard dynamic panel model aiming to assess the effect of innovations on unemployment taking into account different levels of innovativeness of the European Union countries.

The following sections are covered in the paper: theoretical analysis, research design, results, and conclusions. 
Theoretical Analysis of Technological Innovations and their Impact on Labour Market Parameters

J. A. Schumpeter was the first who created the contemporary conception of innovations in the 20th century, characterizing this phenomenon as the core of economic development which breaks the economy out of its static regime and sets it on a dynamic path of fits and starts. This phenomenon is called creative destruction (Schumpeter, 2008). As Schumpeter (2017) notices, technological breakthroughs cannot be considered as innovations if they do not stimulate the growth of net profit or economic. In the 20th century, J. A. Schumpeter emphasized technological innovations in terms of market experiments and sought significant changes that could fundamentally restructure industries and markets (OECD/Eurostat, 2005).

OECD/Eurostat (2019) 2018 the Oslo Manual distinguishes two types of innovations: product and business process. Product innovations involve significant changes in products or services (Gault, 2018). Business process innovations are related to one or more new or significantly improved business process functions (OECD/Eurostat, 2019). There is also a more general division of innovations into: technological (associated with the use of ideas and knowledge to achieve a commercially successful product, process or service (Lithuanian Innovation Centre, 2012; Schramm, 2017)) and non-technological (these are noncommercial innovations related to practical marketing or operational changes in the organization (Lithuanian Innovation Centre, 2012; Schramm, 2017)). It should also be mentioned that there are other types of innovations distinguished by scientists: marketing, socio-psychological, organizational, evolutionary, etc. This paper focuses on technological innovations, including product and process innovations, because, as defined by Hoover (2012) and Ramanauskiene (2010), technological innovations are two types: product (related to the waves of new technologies) and process (related to the emergence of new methods of process of production organization) (Schramm, 2017). Product innovations provide innovative products on a market and a stimulated demand causes a positive link between innovation and employment (Vivarelli, 2014; Marcolin et al., 2016; etc.). Process innovations usually replace labour with new mechanisms, equipments and improve firms' efficiency and productivity, leading to job losses (Peters, 2004; Vivarelli, 2014; etc.). However, it should be noted that there are different results of the researches about the impact of process innovations: positive effects on employment have been obtained (Greenhalgh et al., 2001; Lachenmaier \& Rottmann, 2011; etc.), negative (Van Reenen, 1997; Dachs \& Peters, 2014; Falk, 2015; etc.) or the results have been insignificant (Hall et al., 2008; Harrison et al., 2008). In addition, as Dachs \& Peters (2014) argue, at firm level, both product and process innovations can be related to a lower demand for labour force. This factor can reduce employment (called crowding out effect) or to lead to a higher employment (called compensatory effect).

Moreover, Dachs \& Peters (2014) distinguish additional innovation effects on employment at sectoral or macro level. Process innovations can affect employment in upstream companies if they acquire new machines to enhance the process of production. Indirect effect can emerge if an innovative company increases its production - supplying companies benefit from the growth of production and can stimulate demand for labour. From the other side, competing companies that don't have possibility go along with new technologies, can lose market share (loss of workplaces). Product innovation can also lead to positive and negative external factors for other companies in the same or another industry. Product innovations create negative externalities if an innovative company increases production at the expense of existing products of other companies. At sectoral and macro levels, these effects for available products need to be considered (Dachs \& Peters, 2014).

As Autor (2015) notices, technological changes don't affect a long-run increase in unemployment but they have an impact on the types of workplaces. Based on this idea, some people have a high, medium or low risk to be changed by machines (Frey \& Osborne, 2017). Loi (2015) states that information and communication technologies affect elimination of human workplaces, especially in the middle-class jobs. The scientist mentioned the term of humanistic fallacy, pursuing to describe the idea that the replacement of people work by machines basically will mean that people will have better jobs than their present workplaces. Brynjolfsson \& McAfee (2011) also mention the idea about considerable changes made by computerization and the authors notice that these changes can be very worthy. Innovations can be understood as a creator of new knowledge in the country, as an agent for potential spread of knowledge, and as a factor to contribute a diffusion potential (KondratiukNierodzinska, 2016). Innovations are a key factor of social and economic development. They are as an influential process, giving opportunities to benefit for the whole society. The commercialization of innovations is a fundamental condition for the creation of competitiveness and the growth of economy (Bracio \& Szarucki, 2019). Bracio \& Szarucki (2019) mentioned that innovations and internationalization are the factors that can affect company's growth if they work together.

Mokyr et al. (2015) distinguish two concerns: first, new technologies can provoke a replacement of labour force with machines (the result is technological unemployment); second, there can be a concern about the moral aspects of technological change for human prosperity (a routine nature of work). Fuller (2019) talks about two possible consequences of technological progress as well, but the main attention is concentrated on different terms. According to the author, in the short-term, many manual or low skill jobs can be replaced by machinery; in the long-term, people can gain special skills for tasks which cannot be performed by machines.

Taking into account that the results of theoretical literature reveal an ambiguous answer about the effect of technological innovations on unemployment, more attention should be paid to empirical analysis that can take into consideration various kinds of innovations, their effect on different labour market parameters, direct and indirect effects, different methods for the evaluation of the effect and other measures.

Empirical researches assessing the relationship between technological change and labour market parameters can be divided according to the level of analysis: macro, sectoral and micro. It should be noted that most recent empirical 
researches analyzing the link between innovation and employment assess the micro level effect and it can be detected relatively few researches on the effect of macro level technological innovations on labour market parameters research. Vivarelli (2011) identifies three main challenges in assessing the effect of innovations on employment at the macro level: first, it is complicated to measure innovations; second, the ultimate effect of innovations on employment depends on different institutional mechanisms; third, it is complicated to define the ultimate effect of innovations on employment from the moment employment is affected by many other factors, such as labour market dynamics, the macroeconomic environment, and etc. However, it should be noted, that macro level researches have an advantage over micro and sectoral level researches, because they examine the impact on the economy as a whole. Sectoral level researches do not assess the cross-sectoral indirect (compensatory) effect of technological change. Micro econometric researches can't completely evaluate indirect compensatory effects, that occur not only at the company level, but also through inter sectoral relationships.

It should be noted that macro level researches on the effect of innovations on labour market parameters don't provide a clear answer: some of them prove a positive effect, some - negative, and some of them present a non-significant or unclear findings. Hence, these are the reasons to investigate a macro level research: 1 . only few macro level researches; 2. no clear answer what effect technological innovations have on unemployment; 3 . no one of the macro level researches used a modified form of dynamic panel model. As this research analyses the effect of technological innovations on unemployment at macro level, only empirical analysis at this level are useful in revealing the ways product and process innovations generate jobs or destroy them (see Table 1).

Table 1

Macro Level Researches of the Effect of Innovations on Labour Market Parameters (1990-2016)

\begin{tabular}{|c|c|c|c|c|c|}
\hline \multirow[b]{2}{*}{ Author(s), year } & \multirow[b]{2}{*}{ Measurement instrument of innovations } & \multirow{2}{*}{$\begin{array}{l}\text { Labour market } \\
\text { parameter }\end{array}$} & \multicolumn{3}{|c|}{ Impact } \\
\hline & & & Positive & Negative & Unclear \\
\hline Pini (1995) & Expenditure on R\&D, patents & Employment & $\mathrm{X}$ & & $\mathrm{X}$ \\
\hline Vivarelli (1995) & $\begin{array}{l}\text { Number of patents according to applicability to } \\
\text { process and product innovations }\end{array}$ & Employment & $\mathrm{X}$ & $\mathrm{X}$ & \\
\hline Berman \& Machin (2000) & Usage of computers, R\&D intensity & Employment, wages & $\mathrm{X}$ & & \\
\hline Simonetti et al. (2000) & $\begin{array}{c}\text { Number of patents according to applicability to } \\
\text { process and product innovations }\end{array}$ & Employment & $\mathrm{X}$ & & $\mathrm{X}$ \\
\hline Tancioni \& Simonetti (2002) & The growth level of process innovations & Employment & & & $\mathrm{X}$ \\
\hline Gorle \& Clive (2011) & Density of robots & Employment & $\mathrm{X}$ & & \\
\hline Kromann et al. (2011) & Number of industrial robots, ICT capital & Employment & $\mathrm{X}$ & $\mathrm{X}$ & \\
\hline Feldmann (2013) & Triadic patent families & Unemployment & $\mathrm{X}$ & & \\
\hline Evangelista et al. (2014) & ICT variables & Employment & $\mathrm{X}$ & & \\
\hline Jensen \& Koch (2015) & $\begin{array}{l}\text { Probability of job replacement due to } \\
\text { automation }\end{array}$ & Employment & & $\mathrm{X}$ & \\
\hline Gregory et al. (2016) & Computerization & $\begin{array}{l}\text { Labour force } \\
\text { demand }\end{array}$ & $\mathrm{X}$ & & \\
\hline Marcolin et al. (2016) & ICT-intensity, patents & Employment & $X$ & & \\
\hline Matuzeviciute et al. (2017) & Triadic patent families, expenditure on R\&D & Unemployment & & & $\mathrm{X}$ \\
\hline
\end{tabular}

The information provided in Table 1 exposes that the effect of innovations on labour market parameters from the macro level empirical studies is not clear. Hence, empirical analysis which proves the results obtained in different ways is needed that can evaluate the effect of technological innovations on one of the most important macroeconomic indicator - unemployment.

\section{Research Design}

This research encompasses 28 European Union countries. The research period is 1992-2016 (yearly data). Empirical analysis is based on dynamic panel data regression model. The method used in the research two-step system generalized method of moments (GMM-SYS). The general form of dynamic panel data model:

$$
\mathrm{Y}_{\mathrm{it}}=\delta \mathrm{Y}_{\mathrm{i}, \mathrm{t}-1}+\alpha+\beta_{\mathrm{i}} \mathrm{X}_{\mathrm{it}}+\mathrm{c}_{\mathrm{i}} \mathrm{C}_{\mathrm{it}}+\mu_{\mathrm{i}}+\varphi_{\mathrm{t}}+\mathrm{e}_{\mathrm{it}},
$$

here: $Y$ denotes response variable; $Y(-1)$ denotes lagged response variable; the subscripts $i$ and $t$ represent, respectively, cross-sectional unit and time period; $\alpha$ is a constant; $X$ is a core explanatory variable; $\mathrm{C}$ denotes a series of control variables; $\mu$ denotes specific effects of cross-sectional units; $\varphi$ denotes time effects; $\delta, \beta$, c are parameters that indicate the effect of the right-hand side variables on response variable; $\mathrm{e}$ is the error term (Lachenmaier \& Rottmann, 2011).

This form is modified pursuing to reflect the level of innovativeness:

$$
\mathrm{Y}_{\mathrm{it}}=\delta \mathrm{Y}_{\mathrm{i}, \mathrm{t}-1}+\alpha+\beta_{\mathrm{i}} \mathrm{X}_{\mathrm{it}}+\gamma_{\mathrm{i}} \mathbf{X}^{2}{ }_{\mathrm{it}}+\mathrm{c}_{\mathrm{i}} \mathrm{C}_{\mathrm{it}}+\mu_{\mathrm{i}}+\varphi_{\mathrm{t}}+\mathrm{e}_{\mathrm{it}},
$$

where $\mathrm{X}^{2}$ shows that the effect of innovations on unemployment may be non-linear.

Two core independent variables of the research are R\&D expenditure (\% of gross domestic product; reflects product innovations; $r d$ ) and number of patent applications (per million population; reflects process innovations; $p a t$ ). The dependent variable of the research is unemployment (\% of total labour force; unem). Also, this research distinguishes variables that have an effect on unemployment and that will be used as control variables in the research:

- Collective bargaining coverage (a part of employees who have the right to bargain; $c b c$ ). This indicator shows what effect collective bargaining has on employment (OECD/Eurostat, 2005). In 1988 Calmfors \& Driffill provided an argument which relates collective bargaining and unemployment (national level): people who make a decision about wage setting, take into consideration "broader interests" and internalize the effects of salary 
growth and taxes that are needed for unemployment benefits funding (Jimeno \& Thomas, 2011). According to Feldmann (2013), if a rate of collective bargaining coverage is high, it is highly possible that it will affect an increase in unemployment.

- Consumer price index, CPI $(2010=100 ;$ cpi $)$, is called as the main measure of inflation. Traditionally the relationship between inflation and unemployment has an inverse form, named the Phillips curve. Recent research by Malikane \& Mokoka (2014) proved that when inflation increases, unemployment decreases.

- Foreign direct investment, FDI (inward stocks of FDI ( $\%$ of GDP), fdi_inw; outward stocks of FDI (\% of GDP), fdi_out). According to Lipsey et al. (2010), net inward investment reduces unemployment and net outward investment can have different influence. As Muhd Irpan et al. (2016) notice, both inward and outward foreign direct investments lower unemployment rate in developing countries. As O. Blanchard mentioned in 2011, high unemployment rates' countries are attractive for foreign investors because of these reasons: first, many of workers and, second, high possibility to find a proper worker who would work with a lower wage (Strat et al., 2015).

- Gross domestic product, GDP (GDP per capita; $g d p)$. As Meidani \& Zabihi (2011) emphasize, the link between GDP and unemployment is usually negative. According to the Okun's law, in order to reach a one percentage point decrease in unemployment rate per year, real GDP should increase about two percentage points faster than the rate of potential GDP growth over that year (Misini \& Badivuku-Pantina, 2017).

- Gross fixed capital formation (\% of GDP; $g f c f$ ). This indicator reflects purchases and establishment of assets by manufacturers for their own usage, minus disposals of produced fixed assets (OECD, 2019). This variable is used to measure capital since the demand for labour is affected by capital either through a substitution effect (more capital is used instead of workers) or through a complementarity effect (more capital is needed in association with additional workers) (Marcolin et al., 2016).

- Import (\% of GDP, imp) and export (\% of GDP, exp). New growth theory sees international trade as a major source of international technology (Grossman \& Helpman, 1994). The spread of international technology can stimulate innovation activity, possibly influencing competition in patents (Halmenschlager, 2006). In addition, these indicators have an immediate effect on unemployment: from one point of view, rising import can increase unemployment in industrialized countries because of intensified competition with developing countries for low salaries; from the other point of view, globalization can cause a better international division of labour by increasing employment (Grossmann \& Rossi-Hansberg, 2008).

- Public unemployment spending (\% of GDP; bnf). This indicator is described as money paid for people to offset unemployment (OECD, 2017). Research by Nickell et al. (2005) proved the fact that unemployment spending increases unemployment. As Moffitt (2014) finds, unemployment benefits increase unemployment in a country and unemployed people are encouraged to stay unemployed for longer.
- Tax wedge on labour cost (\% of total labour costs; tax). This indicator is calculated as labour costs that employer suffers minus the net payment for worker - an additional burden for companies. If tax wedge increases, then labour costs that companies suffer grow and thus it indirectly affects unemployment (Separovic, 2009). As Nickell (1997) notices, the impact of tax wedge on unemployment is related to who bears the tax burden.

- Trade union density (a part of employees who are members of trade union; $t u d$ ). This indicator is expressed as the percentage of labour force belonging to trade unions. As Ashley \& Jones (1996) suggest, the density effect increases as unemployment increases. Baccaro \& Rei (2007) state that trade union density can have an effect on unemployment in two different ways: first, increased average salaries; second, compressed wage structure. Blanchard \& Wolfers (2000) revealed that the higher trade union density the higher unemployment.

- Wage bargaining coordination (wbc). This indicator can gain values from 1 to 5 :

- $\quad$ 1: decomposed negotiations for wage;

2: composite negotiations at industry and company

level, weak government coordination;

3: centralized bargaining (negotiation guidelines);

4: centralized bargaining (wage norms);

5: centralized bargaining (maximum or minimum wage) (Visser, 2019).

Since this variable can gain meanings from 1 to 5 , dummy variables must be used. According to the theory of econometrics, the number of dummy variables should be 4 (if there are $n$ categories, then there should be $(n-1)$ dummy variables) but because there are many control variables in this research, the number of dummy variables will be reduced to 3 .

Flanagan (1999) states that coordination of wage bargaining affects decrease in unemployment because this indicator is related to lower real wage than in a case of uncoordinated bargaining. Saint-Paul (2004) notices that a positive link between bargaining coordination and unemployment might be possible as well.

The hypotheses of this research based on the literature review:

$\mathbf{H}_{1}$ : the effect of process innovations on unemployment is positive.

This hypothesis is raised according to Pianta (2000) and Diaconu (2011) who proved that process innovations increase demand and stimulate production and income growth and employment. $\mathrm{H}_{1}$ hypothesis will be accepted if the number of patent applications variable will be statistically significant and positive in at least (not less than) half cases of the model.

$\mathbf{H}_{2}$ : the effect of product innovations on unemployment is negative.

This hypothesis is based on the theoretical attitudes of researchers and the obtained research results. An example is Vivarelli (2011) who argued that product innovations' impact on employment is positive. $\mathrm{H}_{2}$ hypothesis will be accepted if expenditure on $R \& D$ variable will be statistically significant and negative in at least half cases of the model.

$\mathbf{H}_{3}$ : countries' level of innovativeness has an impact on unemployment. 
This hypothesis is based on the assumption that there may be different effects of innovations on unemployment in the countries with different levels of innovativeness. As Acemoglu (2003) and Piva (2003) mentioned, in developing countries technological change is usually imported from developed countries. Hence, the level of innovativeness may have different effects on unemployment rates. $\mathrm{H}_{3}$ hypothesis will be accepted if squared main independent variables will be statistically significant in at least half cases of the model.

$\mathbf{H}_{4}$ : the effect of gross fixed capital formation on unemployment is negative.

This hypothesis is based on the idea that more capital is related to additional workers (Marcolin et al., 2016). $\mathrm{H}_{4}$ hypothesis will be accepted if gross fixed capital formation (\% of GDP) variable will be negative and statistically significant in at least half of the cases of the model.

This methodology is new in the field of analyzing the effect of innovations on unemployment. It enables to compare the results with the previous research and evaluate the aspect of innovativeness.

\section{Results}

The descriptive statistics of the research variables are provided in Table 2. Outliers have been removed from the dataset.

Table 2

Descriptive Statistics of the Research Variables

\begin{tabular}{|c|c|c|c|c|c|}
\hline Variable & Mean & Median & St.Dev. & Min & Max \\
\hline unem & 9,221 & 8,165 & 4,498 & 1,800 & 27,470 \\
pat & 227,900 & 103,000 & 236,100 & 7,000 & 1069,000 \\
\hline rd & 1,396 & 1,220 & 0,833 & 0,200 & 3,910 \\
\hline fdi_inw & 78,000 & 31,520 & 211,500 & 0,587 & 1812,000 \\
\hline fdi_out & 52,170 & 14,860 & 131,000 & 0,003 & 1013,000 \\
\hline gdp & 25855 & 24138 & 14491 & 4497 & 102500 \\
\hline wbc & 2,706 & 2,000 & 1,286 & 1,000 & 5,000 \\
cbc & 65,460 & 70,700 & 26,450 & 7,100 & 100,000 \\
\hline
\end{tabular}

\begin{tabular}{|c|c|c|c|c|c|}
\hline Variable & Mean & Median & St.Dev. & Min & Max \\
\hline cpi & 83,280 & 86,310 & 22,860 & 0,241 & 114,900 \\
tud & 33,610 & 27,680 & 21,040 & 1,000 & 93,900 \\
bnf & 1,335 & 1,000 & 0,985 & 0,000 & 5,4000 \\
tax & 37,550 & 39,300 & 8,460 & 11,600 & 51,400 \\
imp & 52,620 & 45,430 & 27,910 & 17,410 & 187,500 \\
\hline exp & 53,520 & 44,970 & 32,330 & 14,050 & 222,700 \\
\hline gff & 22,200 & 21,880 & 4,092 & 5,388 & 37,360 \\
\hline
\end{tabular}

The coefficient of correlation between three pairs of variables is high, therefore, in order to estimate the model for robustness check, these variables are included separately to the model. In total, 12 estimations are performed. Table 3 presents the results of estimations I-VI. All estimations passed Sargan and AR(2) tests and it means that instruments are valid and the results are not influenced by second-order serial correlation.

II and IV estimations in Table 3 suggest that product innovations $(r d)$ have an impact on unemployment. These estimations show a negative correlation (the more product innovations the lower the rate of unemployment). This statement can be based on the results of the research of Vivarelli (2015) who proved that expenditure for R\&D is related to the development of new job places and thus has a negative correlation with unemployment.

Two control variables are statistically significant in all estimations presented in Table 3:

- Public unemployment spending variable has a negative effect (positive sign near coefficient) - it increases unemployment. The result can be based on the statements provided by Nickell et al. (2005) and Moffitt (2014).

- Gross fixed capital formation has a positive effect (negative sign near coefficient): it decreases unemployment and has a complementarity effect - more capital is needed in association with additional workers.

Other control variables of the model are statistically insignificant or the effect on unemployment is statistically significant only in one or few of the cases.

Table 3

Estimation Results with a Core $\boldsymbol{r d}$ Independent Variable

\begin{tabular}{|c|c|c|c|c|c|c|}
\hline Regressors & I & II & III & IV & $\mathbf{V}$ & VI \\
\hline l_unem(-1) & $\begin{array}{c}0,5883 * * * \\
(0,0000)\end{array}$ & $\begin{array}{c}0,5282 * * * \\
(0,0000)\end{array}$ & $\begin{array}{c}0,5806 * * * \\
(0,0000)\end{array}$ & $\begin{array}{c}0,5175 * * * \\
(0,0000)\end{array}$ & $\begin{array}{c}0,5562 * * * \\
(0,0000)\end{array}$ & $\begin{array}{c}0,5562 * * * \\
(0,0000)\end{array}$ \\
\hline const & $\begin{array}{c}2,9256 \\
(0,3462)\end{array}$ & $\begin{array}{c}1,3293 \\
(0,5383)\end{array}$ & $\begin{array}{c}2,7714 \\
(0,3757)\end{array}$ & $\begin{array}{c}1,3512 \\
(0,5350)\end{array}$ & $\begin{array}{l}-0,4744 \\
(0,8323)\end{array}$ & $\begin{array}{l}-0,4801 \\
(0,8282)\end{array}$ \\
\hline$l \_r d$ & $\begin{array}{l}-0,1739 \\
(0,2081)\end{array}$ & $\begin{array}{c}-0,2080 * * * \\
(0,0001)\end{array}$ & $\begin{array}{l}-0,1782 \\
(0,1891)\end{array}$ & $\begin{array}{c}-0,2078 * * * \\
(0,0001)\end{array}$ & $\begin{array}{l}-0,2610 \\
(0,1189)\end{array}$ & $\begin{array}{l}-0,2652 \\
(0,1134)\end{array}$ \\
\hline$s q \_l \_r d$ & $\begin{array}{c}0,0419 \\
(0,6182)\end{array}$ & $\begin{array}{c}0,0218 \\
(0,7386)\end{array}$ & $\begin{array}{c}0,0519 \\
(0,5445)\end{array}$ & $\begin{array}{c}0,0307 \\
(0,6377)\end{array}$ & $\begin{array}{c}0,0304 \\
(0,7445)\end{array}$ & $\begin{array}{c}0,0312 \\
(0,7409)\end{array}$ \\
\hline$l \_b n f$ & $\begin{array}{l}0,1237 * \\
(0,0604) \\
\end{array}$ & $\begin{array}{c}0,1500 * * * \\
(0,0051)\end{array}$ & $\begin{array}{l}0,1217^{*} \\
(0,0710)\end{array}$ & $\begin{array}{c}0,1571 * * * \\
(0,0049) \\
\end{array}$ & $\begin{array}{c}0,1454 * * * \\
(0,0007)\end{array}$ & $\begin{array}{c}0,1462 * * * \\
(0,0008)\end{array}$ \\
\hline$l \_t a x$ & $\begin{array}{c}0,4269 \\
(0,1840)\end{array}$ & $\begin{array}{c}0,3267 \\
(0,1624)\end{array}$ & $\begin{array}{c}0,4663 \\
(0,1611) \\
\end{array}$ & $\begin{array}{c}0,3613 \\
(0,1052)\end{array}$ & $\begin{array}{c}0,6393 \\
(0,1129) \\
\end{array}$ & $\begin{array}{c}0,6526 \\
(0,1043) \\
\end{array}$ \\
\hline$l \_g f c f$ & $\begin{array}{c}-0,6874 * * \\
(0,0144)\end{array}$ & $\begin{array}{c}-0,4441 * * \\
(0,0408)\end{array}$ & $\begin{array}{c}-0,7549 * * \\
(0,0109)\end{array}$ & $\begin{array}{c}-0,5146^{* *} \\
(0,0253)\end{array}$ & $\begin{array}{c}-0,5902 * * * \\
(0,0062)\end{array}$ & $\begin{array}{c}-0,6065 * * * \\
(0,0087)\end{array}$ \\
\hline l_tud & $\begin{array}{l}-0,0742 \\
(0,3432)\end{array}$ & $\begin{array}{l}-0,0880 \\
(0,3547)\end{array}$ & $\begin{array}{l}-0,0683 \\
(0,3891)\end{array}$ & $\begin{array}{l}-0,0864 \\
(0,3539)\end{array}$ & $\begin{array}{c}0,0046 \\
(0,9579)\end{array}$ & $\begin{array}{c}0,0043 \\
(0,9607)\end{array}$ \\
\hline$l \_c b c$ & $\begin{array}{l}-0,0721 \\
(0,5293)\end{array}$ & $\begin{array}{l}-0,0484 \\
(0,6828)\end{array}$ & $\begin{array}{l}-0,0784 \\
(0,4732)\end{array}$ & $\begin{array}{l}-0,0542 \\
(0,6494)\end{array}$ & $\begin{array}{l}-0,0760 \\
(0,5641)\end{array}$ & $\begin{array}{l}-0,0726 \\
(0,5971)\end{array}$ \\
\hline l_fdi_inw & $\begin{array}{c}0,0750 \\
(0,1397)\end{array}$ & $\begin{array}{c}0,0675 \\
(0,1085)\end{array}$ & $\begin{array}{c}0,0751 \\
(0,1100)\end{array}$ & $\begin{array}{l}0,0645 * \\
(0,0903)\end{array}$ & & \\
\hline l_fdi_out & & & & & $\begin{array}{c}0,0010 \\
(0,9852)\end{array}$ & $\begin{array}{c}0,0010 \\
(0,9863)\end{array}$ \\
\hline
\end{tabular}


Zigmas Lydeka, Akvile Karaliute. Assessment of the Effect of Technological Innovations on Unemployment in the...

\begin{tabular}{|c|c|c|c|c|c|c|}
\hline Regressors & $\mathbf{I}$ & II & III & IV & $\mathbf{V}$ & VI \\
\hline$l \_g d p$ & $\begin{array}{l}-0,0770 \\
(0,6874) \\
\end{array}$ & & $\begin{array}{l}-0,0569 \\
(0,7692) \\
\end{array}$ & & & \\
\hline$l_{-} c p i$ & & $\begin{array}{c}0,1375 \\
(0,3797)\end{array}$ & & $\begin{array}{c}0,1407 \\
(0,3463)\end{array}$ & $\begin{array}{c}0,2701 \\
(0,1264)\end{array}$ & $\begin{array}{c}0,2619 \\
(0,1497)\end{array}$ \\
\hline l_imp & $\begin{array}{l}-0,1095 \\
(0,3758) \\
\end{array}$ & $\begin{array}{l}-0,1419 \\
(0,1441) \\
\end{array}$ & & & & $\begin{array}{c}0,0041 \\
(0,9533) \\
\end{array}$ \\
\hline l_exp & & & $\begin{array}{l}-0,1019 \\
(0,3274) \\
\end{array}$ & $\begin{array}{l}-0,1153 \\
(0,1282) \\
\end{array}$ & $\begin{array}{l}-0,0044 \\
(0,9313) \\
\end{array}$ & \\
\hline$w b c_{-} l$ & $\begin{array}{l}-0,0147 \\
(0,9302)\end{array}$ & $\begin{array}{c}0,0925 \\
(0,5138)\end{array}$ & $\begin{array}{l}-0,0149 \\
(0,9305)\end{array}$ & $\begin{array}{c}0,0856 \\
(0,5707)\end{array}$ & $\begin{array}{c}0,0825 \\
(0,5502)\end{array}$ & $\begin{array}{c}0,0819 \\
(0,5544)\end{array}$ \\
\hline$w b c \_2$ & $\begin{array}{l}-0,0117 \\
(0,8971)\end{array}$ & $\begin{array}{c}0,0140 \\
(0,8302)\end{array}$ & $\begin{array}{l}-0,0018 \\
(0,9843)\end{array}$ & $\begin{array}{c}0,0191 \\
(0,7803)\end{array}$ & $\begin{array}{c}0,0704 \\
(0,2457)\end{array}$ & $\begin{array}{c}0,0708 \\
(0,2399)\end{array}$ \\
\hline$w b c \_3$ & $\begin{array}{c}0,0732 \\
(0,4964) \\
\end{array}$ & $\begin{array}{l}0,1253 * * \\
(0,0345)\end{array}$ & $\begin{array}{c}0,0806 \\
(0,4363) \\
\end{array}$ & $\begin{array}{l}0,1327 * * \\
(0,0355)\end{array}$ & $\begin{array}{l}0,1239^{*} \\
(0,0591) \\
\end{array}$ & $\begin{array}{l}0,1238^{*} \\
(0,0702)\end{array}$ \\
\hline Error AR(2) test & $\begin{array}{l}-1,6311 \\
(0,1029)\end{array}$ & $-1,4515(0,1466)$ & $\begin{array}{l}-1,6413 \\
(0,1007)\end{array}$ & $-1,4686(0,1419)$ & $\begin{array}{l}-1,7243 \\
(0,0847)\end{array}$ & $-1,7394(0,0820)$ \\
\hline $\begin{array}{c}\text { Sargan } \\
\text { over-identification test }\end{array}$ & $\begin{array}{l}18,5969 \\
(1,0000)\end{array}$ & $13,9578(1,0000)$ & $\begin{array}{l}18,1651 \\
(1,0000)\end{array}$ & $13,8165(1,0000)$ & $15,7766(1,0000)$ & $15,8386(1,0000)$ \\
\hline Number of countries & 28 & 28 & 28 & 28 & 28 & 28 \\
\hline Number of observations & 321 & 321 & 321 & 321 & 320 & 320 \\
\hline
\end{tabular}

Note: all variables are logged. All estimations are two step GMM-SYS. z-scores are presented in parentheses of estimates. *, **, *** indicate significance at the 10, 5 and 1 percent level, respectively. p-value of AR(2) and Sargan tests is presented in parentheses. The program used for estimations is GRETL.

Table 4 provides the results of estimations VII-XII. All estimations passed Sargan and AR(2) tests and it means that instruments are valid and the results are not influenced by second-order serial correlation. All estimations in Table 4 suggest that process innovations (pat) don't have a statistically significant effect on unemployment. The result can be based on the results of the research of Pini (1995) and
Simonetti et al. (2000) who didn't find any evidence about the impact of process innovations on unemployment.

There are only three control variables - public unemployment spending $(b n f)$, gross fixed capital formation $(g f c f)$ and wage bargaining coordination $\left(w b c \_3\right)-$ that are statistically significant in one or two of six estimations each.

Estimation Results with a Core pat Independent Variable

Table 4

\begin{tabular}{|c|c|c|c|c|c|c|}
\hline Regressors & VII & VIII & IX & $\mathbf{X}$ & XI & XII \\
\hline l_unem(-1) & $\begin{array}{c}0,5995 * * * \\
(0,0000) \\
\end{array}$ & $\begin{array}{c}0,6132 * * * \\
(0,0001)\end{array}$ & $\begin{array}{c}0,5981 * * * \\
(0,0001)\end{array}$ & $\begin{array}{c}0,6312 * * * \\
(0,0001)\end{array}$ & $\begin{array}{c}0,6686^{* * * *} * \\
(0,0000)\end{array}$ & $\begin{array}{c}0,6571 \text { **** } \\
(0,0000)\end{array}$ \\
\hline const & $\begin{array}{c}2,1061 \\
(0,3624) \\
\end{array}$ & $\begin{array}{c}2,0651 \\
(0,2800)\end{array}$ & $\begin{array}{c}2,1992 \\
(0,3443)\end{array}$ & $\begin{array}{c}1,5147 \\
(0,4560) \\
\end{array}$ & $\begin{array}{c}0,4094 \\
(0,8471) \\
\end{array}$ & $\begin{array}{c}0,5980 \\
(0,7772)\end{array}$ \\
\hline l_pat & $\begin{array}{c}0,0453 \\
(0,9229) \\
\end{array}$ & $\begin{array}{l}-0,1285 \\
(0,8168) \\
\end{array}$ & $\begin{array}{c}0,0629 \\
(0,8934) \\
\end{array}$ & $\begin{array}{l}-0,0873 \\
(0,8684)\end{array}$ & $\begin{array}{c}0,1164 \\
(0,7994) \\
\end{array}$ & $\begin{array}{c}0,0313 \\
(0,9481) \\
\end{array}$ \\
\hline$s q \_l \_p a t$ & $\begin{array}{l}-0,0143 \\
(0,7472) \\
\end{array}$ & $\begin{array}{c}0,0024 \\
(0,9644)\end{array}$ & $\begin{array}{l}-0,0157 \\
(0,7237)\end{array}$ & $\begin{array}{l}-0,0012 \\
(0,9816)\end{array}$ & $\begin{array}{l}-0,0192 \\
(0,6590)\end{array}$ & $\begin{array}{l}-0,0107 \\
(0,8145)\end{array}$ \\
\hline l_bnf & $\begin{array}{l}0,1377 * \\
(0,0690)\end{array}$ & $\begin{array}{c}0,1333 \\
(0,1150)\end{array}$ & $\begin{array}{l}0,1391 * \\
(0,0799)\end{array}$ & $\begin{array}{c}0,1167 \\
(0,1730)\end{array}$ & $\begin{array}{c}0,0917 \\
(0,1769)\end{array}$ & $\begin{array}{c}0,1014 \\
(0,1159)\end{array}$ \\
\hline l_tax & $\begin{array}{c}0,1304 \\
(0,3588)\end{array}$ & $\begin{array}{c}0,0859 \\
(0,6274)\end{array}$ & $\begin{array}{c}0,1197 \\
(0,4313)\end{array}$ & $\begin{array}{c}0,1176 \\
(0,5837)\end{array}$ & $\begin{array}{c}0,1208 \\
(0,5045)\end{array}$ & $\begin{array}{c}0,1196 \\
(0,5078)\end{array}$ \\
\hline$l \_g f c f$ & $\begin{array}{l}-0,3889 \\
(0,1050)\end{array}$ & $\begin{array}{l}-0,3776 \\
(0,1656) \\
\end{array}$ & $\begin{array}{c}-0,4097 * \\
(0,0990)\end{array}$ & $\begin{array}{l}-0,3923 \\
(0,1439)\end{array}$ & $\begin{array}{l}-0,4663 \\
(0,1093) \\
\end{array}$ & $\begin{array}{l}-0,4643 \\
(0,1007)\end{array}$ \\
\hline l_tud & $\begin{array}{l}-0,0620 \\
(0,3862)\end{array}$ & $\begin{array}{l}-0,0569 \\
(0,5364)\end{array}$ & $\begin{array}{l}-0,0685 \\
(0,3788)\end{array}$ & $\begin{array}{c}-0,0445 \\
(0,6717)\end{array}$ & $\begin{array}{l}-0,0284 \\
(0,7525)\end{array}$ & $\begin{array}{l}-0,0292 \\
(0,7403)\end{array}$ \\
\hline$l \_c b c$ & $\begin{array}{c}0,0196 \\
(0,8258)\end{array}$ & $\begin{array}{c}0,0226 \\
(0,8225)\end{array}$ & $\begin{array}{c}0,0169 \\
(0,8490)\end{array}$ & $\begin{array}{c}0,0324 \\
(0,7694)\end{array}$ & $\begin{array}{c}0,0831 \\
(0,4905)\end{array}$ & $\begin{array}{c}0,0807 \\
(0,5042)\end{array}$ \\
\hline$l \_f d i \_i n w$ & $\begin{array}{c}0,0484 \\
(0,2351) \\
\end{array}$ & $\begin{array}{c}0,0188 \\
(0,6297) \\
\end{array}$ & $\begin{array}{c}0,0379 \\
(0,2921) \\
\end{array}$ & $\begin{array}{c}0,0074 \\
(0,8267)\end{array}$ & & \\
\hline l_fdi_out & & & & & $\begin{array}{l}-0,0325 \\
(0,2160)\end{array}$ & $\begin{array}{c}-0,0333 \\
(0,2138)\end{array}$ \\
\hline$l \_g d p$ & $\begin{array}{c}-0,0259 \\
(0,8644)\end{array}$ & & $\begin{array}{c}-0,0326 \\
(0,8386)\end{array}$ & & & \\
\hline l_cpi & & $\begin{array}{c}0,0678 \\
(0,7914)\end{array}$ & & $\begin{array}{c}0,1105 \\
(0,6783)\end{array}$ & $\begin{array}{c}0,1964 \\
(0,4323)\end{array}$ & $\begin{array}{c}0,2039 \\
(0,4122)\end{array}$ \\
\hline l_imp & $\begin{array}{l}-0,0582 \\
(0,5472)\end{array}$ & $\begin{array}{l}-0,0372 \\
(0,7285)\end{array}$ & & & & $\begin{array}{c}0,0386 \\
(0,6540)\end{array}$ \\
\hline l_exp & & & $\begin{array}{l}-0,0296 \\
(0,6889)\end{array}$ & $\begin{array}{r}-0,0105 \\
(0,9016)\end{array}$ & $\begin{array}{c}0,0354 \\
(0,6028)\end{array}$ & \\
\hline$w b c_{-} 1$ & $\begin{array}{c}0,1258 \\
(0,4536)\end{array}$ & $\begin{array}{c}0,1426 \\
(0,4733)\end{array}$ & $\begin{array}{c}0,1092 \\
(0,5077)\end{array}$ & $\begin{array}{c}0,1304 \\
(0,5088)\end{array}$ & $\begin{array}{c}0,1063 \\
(0,5350)\end{array}$ & $\begin{array}{c}0,1210 \\
(0,4902)\end{array}$ \\
\hline$w b c \_2$ & $\begin{array}{c}0,0030 \\
(0,9494)\end{array}$ & $\begin{array}{c}0,0128 \\
(0,7890)\end{array}$ & $\begin{array}{l}-0,0094 \\
(0,8451)\end{array}$ & $\begin{array}{c}0,0158 \\
(0,7249)\end{array}$ & $\begin{array}{c}0,0221 \\
(0,6045)\end{array}$ & $\begin{array}{c}0,0277 \\
(0,5347)\end{array}$ \\
\hline$w b c_{2} 3$ & $0,1837^{*}$ & 0,1773 & 0,1846 & 0,1603 & 0,1095 & 0,1181 \\
\hline
\end{tabular}




\begin{tabular}{|c|c|c|c|c|c|c|}
\hline Regressors & VII & VIII & IX & X & XI & XII \\
\hline & $(0,0695)$ & $(0,1577)$ & $(0,1023)$ & $(0,1777)$ & $(0,1861)$ & $(0,1692)$ \\
\hline Error AR(2) test & $-1,6339$ & $-1,7142$ & $-1,7077$ & $-1,8223(0,0684)$ & $-1,9523(0,0509)$ & $-1,9224$ \\
$(0,1023)$ & $(0,0865)$ & $(0,0877)$ & & $(0,0546)$ \\
\hline $\begin{array}{c}\text { Sargan over-identification } \\
\text { test }\end{array}$ & 18,4015 & 19,7075 & 19,3138 & $20,1485(1,0000)$ & $19,8063(1,0000)$ & 19,8696 \\
$(1,0000)$ & $(1,0000)$ & $(1,0000)$ & 28 & 28 & 28 \\
\hline Number of countries & 28 & 28 & 28 & 311 & 310 & 310 \\
\hline Number of observations & 311 & 311 & 311 & $2800)$ & \\
\hline
\end{tabular}

Note: all variables are logged. All estimations are two step GMM-SYS. z-scores are presented in parentheses of estimates. * **. *** indicates significance at the 10, 5 and 1 percent level, respectively. p-value of AR(2) and Sargan tests is presented in parentheses. The program used for estimations is GRETL.

In general, some (less than half) of the presented estimations suggest that product innovations, measured by expenditure on $\mathrm{R} \& \mathrm{D}$, have a statistically significant and positive effect (negative correlation) on unemployment but there is no evidence about the impact of process innovations, measured by the number of patent applications, on unemployment. For this reason, $\mathrm{H}_{1}$ and $\mathrm{H}_{2}$ hypotheses of this research are rejected. There is no evidence about the effect of innovativeness, hence, $\mathrm{H}_{3}$ hypothesis is rejected as well. There are two main control variables that have an effect on unemployment: gross fixed capital formation (in all cases it decreases unemployment, i.e. it has a complementarity effect - more capital means more additional labour force) and public unemployment spending (in all cases it increases unemployment, i.e. more benefits people can get, more likely they are encouraged to stay unemployed for longer). Regarding to this, $\mathrm{H}_{4}$ hypothesis is accepted.

\section{Conclusions}

The answer about the link between technological innovations and unemployment both from theoretical and empirical studies is ambiguous. Theoretical analysis reveals different mechanisms that have different effects at macro, micro, and sectoral levels. These effects are not always direct. There are indirect effects that are linked to compensation mechanisms. Empirical studies also provide different results about the impact of product and process innovations on unemployment. Hence, the aim of

this research is to evaluate the effect of technological innovations on unemployment introducing three novelties: macro level analysis, two core independent variables, and a modified form of the standard dynamic panel data model. The latter novelty is related to the inclusion of squared core independent variables to the model, pursuing to reflect the idea about innovativeness. Using GMM-SYS, authors perform 12 estimations of the model and provide the result that in some cases the link between product innovation and unemployment is statistically significant while the link between process innovation and unemployment is not statistically significant. The hypotheses about the positive impact of process innovations $\left(\mathrm{H}_{1}\right)$ and the negative impact of product innovations $\left(\mathrm{H}_{2}\right)$ on unemployment are rejected since the results are statistically significant in less than half cases of the model. There is no evidence about the effect of innovativeness, hence, $\mathrm{H}_{3}$ hypothesis about the impact of countries' level of innovativeness on unemployment is rejected as well. Two main control variables - public unemployment spending and gross fixed capital formation have a statistically significant effect on unemployment in many cases of the model. Hence, $\mathrm{H}_{4}$ hypothesis about the negative effect of gross fixed capital formation on unemployment is accepted. Other control variables don't have or almost (only 1 or 2 cases from 12 cases are statistically significant) don't have a statistically significant impact on unemployment.

This research implements few new ideas of the methodology, includes 12 control variables and proves the results about the effect of technological innovations on unemployment in a new way.

The results of this research are mostly important at macro level and could be as a guide for people making decisions in countries. Also, these results are relevant at micro level since companies can gain competitive market and be leaders in innovations which is an important factor to stay in a market.

The limitation of this research can be the measurement of unemployment as it is a broad and very important macro level variable and it is difficult to capture the effects of technological innovations.

Further studies could analyze unemployment by types (long-term, structural, and/or other types) for more detailed analysis or by different levels of education to implement the idea of skill-biased technological change. Also, future studies could include other controls, such as public debt, employment protection legislation index and others, to include lagged core independent variables in order to capture a lagged effect on unemployment or to choose different measurement instruments of product and process innovations.

\section{References}

Acemoglu, D. (2003). Patterns of Skill Premia. Review of Economic Studies, 70(2), 199-230. https://doi.org/10.1111/1467$937 X .00242$

Ashley, T., \& Jones, E. B. (1996). Unemployment, Union Density, and Wages. Journal of Labour Research, 17(1), $173-182$. https://doi.org/10.1007/BF02685791

Autor, D. H. (2015). Why Are There Still So Many Jobs? The History and Future of Workplace Automation. Journal of Economic Perspectives, 29(3), 3-30. https://doi.org/10.1257/jep.29.3.3 
Baccaro, L., \& Rei, D. (2007). Institutional Determinants of Unemployment in OECD Countries: Does the Deregulatory View Hold Water? International Organization, 61(3), 527-569. https://doi.org/10.1017/S0020818307070221

Berman, E., \& Machin, S. (2000). Skill-Biased Technology Transfer around the World. Oxford Review of Economic Policy, 16(3), 12-22. https://doi.org/10.1093/oxrep/16.3.12

Blanchard, O., \& Wolfers, J. (2000). The Role of Shocks and Institutions in the Rise of European Unemployment: The Aggregate Evidence. The Economic Journal, 110(462), 1-33. https://doi.org/10.1111/1468-0297.00518

Bracio, K., \& Szarucki, M. (2019). Commercialization of Innovations through Internationalization: A Systematic Literature Review. Business: Theory and Practice, 20, 417-431. https://doi.org/10.3846/btp.2019.39

Brynjolfsson, E., \& McAfee, A. (2011). Race against the machine: How the digital revolution is accelerating innovation, driving productivity and irreversibly transforming employment and the economy. Lexington: Digital Frontier Press. eISBN: 978-0-9847251-0-6

Calmfors, L., \& Driffill, J. (1988). Bargaining Structure, Corporatism and Macroeconomic Performance. Economic Policy, 3(6), 14-61. https://doi.org/10.2307/1344503

Dachs, B., \& Peters, B. (2014). Innovation, Employment Growth and Foreign Ownership of Firms: A European Perspective. Research Policy, 43(1), 214-232. https://doi.org/10.1016/j.respol.2013.08.001

Diaconu, M. (2011). Technological Innovation: Concept, Process, Typology and Implications in the Economy. Theoretical and Applied Economics, 563(10), 127-144. ISSN: 1841-8678

Evangelista, R., Guerrieri, P., \& Meliciani, V. (2014). The Economic Impact of Digital Technologies in Europe. Economics of Innovation and New Technology, 23(8), 802-824. https://doi.org/10.1080/10438599.2014.918438

Falk, M. (2015). Employment Effects of Technological and Organizational Innovations: Evidence Based on Linked Firm-Level Data for Austria. Journal of Economics and Statistics, 235(3), 268-285. https://doi.org/10.1515/jbnst2015-0303

Feldmann, H. (2013). Technological Unemployment in Industrial Countries. Journal of Evolutionary Economics, 23(5), 1099-1126. https://doi.org/10.1007/s00191-013-0308-6

Flanagan, R. J. (1999). Macroeconomic Performance and Collective Bargaining: An International Perspective. Journal of Economic Literature, 37(3), 1150-1175. https://doi.org/10.1257/jel.37.3.1150

Frey, C. B., \& Osborne, M. A. (2017). The Future of Employment: How Susceptible Are Jobs to Computerisation? Technological Forecasting \& Social Change, 114(C), 254-280. https://doi.org/10.1016/j.techfore.2016.08.019

Fuller, S. (2019). Technological unemployment as a test of the added value of being human. In M. A. Peters, P. Jandric, A. J. Means (Eds.), Education and technological unemployment (pp. 115-128). Singapore: Springer. ISBN: 978-981-13-6225-5.

Gault, F. (2018). Defining and Measuring Innovation in all Sectors of the Economy. Research Policy, 47(3), 617-622. https://doi.org/10.1016/j.respol.2018.01.007

Gorle, P., \& Clive, A. (2011). Positive Impact of Industrial Robots on Employment. Available from internet: http://www.bara.org.uk/pdf/2013/IFR_Update_Study_Robot_creates_Jobs_2013.pdf.

Greenhalgh, C., Longland, M., \& Bosworth, D. (2001). Technological Activity and Employment in a Panel of UK Firms. Scottish Journal of Political Economy, 48(3), 260-282. https://doi.org/10.1111/1467-9485.00198

Gregory, T., Salomons, A., \& Zierahn, U. (2016). Racing with or Against the Machine? Evidence from Europe. ZEW Discussion Paper No. 16-053. Available from internet: http://ftp.zew.de/pub/zew-docs/dp/dp16053.pdf.

Grossman, G. M., \& Helpman, E. (1994). Endogenous Innovation in the Theory of Growth. Journal of Economic Perspectives, 8(1), 23-44. https://doi.org/10.1257/jep.8.1.23

Grossman, G. M., \& Rossi-Hansberg, E. (2008). Trading Tasks: A Simple Theory of Offshoring. American Economic Review, 98(5), 1978-1997. https://doi.org/10.1257/aer.98.5.1978

Hall, B. H., Lotti, F., \& Mairesse, J. (2008). Employment, Innovation and Productivity: Evidence from Italian Microdata. Industrial and Corporate Change, 17(4), 813-839. https://doi.org/10.1093/icc/dtn022

Halmenschlager, C. (2006). Spillovers and Absorptive Capacity in a Patent Race. The Manchester School, 74(1), 85-102. https://doi.org/10.1111/j.1467-9957.2006.00484.x

Harrison, R., Jaumandreu, J., Mairesse, J., \& Peters, B. (2008). Does Innovation Stimulate Employment? A Firm-level Analysis Using Comparable Micro Data on Four European Countries. NBER Working Paper No. 14216. https://doi.org/10.3386/w14216

Hoover, K. D. (2012). Applied intermediate macroeconomics. New York: Cambridge University Press. ISBN: 0521763886.

Jensen, B., \& Koch, M. (2015). Man and Machine: Robots on the rise? Available from internet: https://www2.deloitte.com/content/dam/Deloitte/ch/Documents/innovation/ch-en-innovation-automation-report.pdf. 
Jimeno, J. F., \& Thomas, C. (2011). Collective Bargaining, Firm Heterogeneity and Unemployment. European Economic Review, 59(C), 63-79. https://doi.org/10.1016/j.euroecorev.2012.11.009

Kondratiuk-Nierodzinska, M. (2016). Innovation Capabilities in EU Countries: Have Central and Eastern European Countries Been Catching up? Journal of Business Economics and Management, 17(5), 765-779. https://doi.org/10.3846/16111699.2015.1114016

Kromann, L., Skaksen, J. R., \& Sorensen, A. (2011). Automation, Labour Productivity and Employment - a Cross Country Comparison. Available from internet: http://www.aim-projekt.dk/files/robot-employment.pdf.

Lachenmaier, S., \& Rottmann, H. (2011). Effects of Innovation on Employment: A Dynamic Panel Analysis. International Journal of Industrial Organization, 29(2), 210-220. https://doi.org/10.1016/j.ijindorg.2010.05.004

Lipsey, R. E., Sjoholm, F., \& Sun, J. (2010). Foreign Ownership and Employment Growth in Indonesian Manufacturing. NBER Working Paper No. 15936, National Bureau of Economic Research. https://doi.org/10.3386/w15936

Lithuanian Innovation Centre (2012). Vartotoju pasiruosimas ir parengimas priimti išmaniaisias technologijas ir inovacijas transporte: marketingas, mokymas, samoningumo didinimas. Available from internet: https://sumin.lrv.lt/ uploads/sumin/documents/files/Veikla/Veiklos_ sritys/Kita_veikla/Seminarai/konferencija-intelektines-transportosistemos/A_Jakubavicius_Vartotojai-technologijos.pdf.

Loi, M. (2015). Technological Unemployment and Human Disenhancement. Ethics and Information Technology, 17(3), 201-210. https://doi.org/10.1007/s10676-015-9375-8

Malikane, C., \& Mokoka, T. (2014). The New Keynesian Phillips Curve: Endogeneity and Misspecification. Applied Economics, 46(25), 3082-3089. https://doi.org/10.1080/00036846.2014.922672.

Marcolin, L. S. M., Miroudot, S., \& Squicciarini, M. (2016). Routine Jobs, Employment and Technological Innovation in Global Value Chains. OECD Science, Technology and Industry Working Papers No. 01. https://doi.org/ 10.13140/RG.2.1.1000.6802

Matuzeviciute, K., Butkus, M., \& Karaliute, A. (2017). Do Technological Innovations Affect Unemployment? Some Empirical Evidence from European Countries. Economies, 48(5), 1-19. https://doi.org/10.3390/economies5040048

Meidani, A. A. N., \& Zabihi, M. (2011). The Dynamic Effect of Unemployment Rate on per Capita Real GDP in Iran. International Journal of Economics and Finance, 3(5), 170-177. https://doi.org/10.5539/ijef.v3n5p170

Misini, S., \& Badivuku-Pantina, M. (2017). The Effect of Economic Growth in Relation to Unemployment. Journal of Economics and Economic Education Research, 18(2), 1-9. ISSN: 1533-3590.

Moffitt, R. (2014). Unemployment Benefits and Unemployment. IZA World of Labor, 13. https://doi.org/10.15 185/izawol.13

Mokyr, J., Vickers, C., \& Ziebarth, N. L. (2015). The History of Technological Anxiety and the Future of Economic Growth: Is This Time Different? Journal of Economic Perspectives, 29(3), 31-50. https://doi.org/10.1257/jep.29.3.31

Muhd Irpan, H., Mat Saad, R., Nor, A. H. S. M., Nor, A. H. M., \& Ibrahim, N. (2016). Impact of Foreign Direct Investment on the Unemployment Rate in Malaysia. Journal of Physics. Conference Series 710(2016) 012028. ISBN: 978-09860419-5-2.

Nickell, S. (1997). Unemployment and Labour Market Rigidities. Europe versus North America. Journal of Economic Perspectives, 11(3), 55-74. https://doi.org/ 10.1257/jep.11.3.55

Nickell, S. N., Nunziata, L., \& Ochel, W. (2005). Unemployment in the OECD Since the 1960s. What Do We Know? Economic Journal, 115(500), 1-27. https://doi.org/10.1111/j.1468-0297.2004.00958.x

OECD (2017). Public Unemployment Spending. Available from internet: https://www.oecd-ilibrary.org/social-issuesmigration-health/public-unemployment-spending/indicator/english_55557fd4-en.

OECD (2019). Investment (GFCF) (Indicator). Available from internet: https://data.oecd.org/gdp/investment-gfcf.htm.

OECD/Eurostat (2005). Oslo Manual: Guidelines for collecting and interpreting innovation data. Paris: OECD Publishing. ISBN: 9789264013100.

OECD/Eurostat (2019). Oslo Manual 2018: Guidelines for collecting, reporting and using data on innovation. Paris, Luxembourg: OECD Publishing. https://doi.org/10.1787/9789264304604-en

Peters, B. (2004). Employment Effects of Different Innovation Activities: Microeconometric Evidence. ZEW - Centre for European Economic Research Discussion Paper 04-73. Available from internet: ftp://ftp.zew.de/pub/zewdocs/dp/dp0473.pdf.

Pianta, M. (2000). The employment impact of product and process innovations. In M. Pianta, M. Vivarelli (Eds.), The employment impact of innovation: Evidence and policy (pp. 77-95). London: Routledge. https://doi.org/10.43 24/9780203458686 
Pini, P. (1995). Economic Growth, Technological Change and Employment: Empirical Evidence for a Cumulative Growth Model with External Causation for Nine OECD Countries: 1960-1990. Structural Change and Economic Dynamics, 6(2), 185-213. https://doi.org/10.1016/0954-349X(94)00008-W

Piva, M. (2003). The Impact of Technology Transfer on Employment and Income Distribution in Developing Countries: A Survey of Theoretical Models and Empirical Studies. International Policy Group Working Paper No. 15.

Piva, M., \& Vivarelli, M. (2005). Innovation and Employment: Evidence from Italian Microdata. Journal of Economics, 86(1), 65-83. https://doi.org/10.1007/s00712-005-0140-z

Ramanauskiene, J. (2010). Inovacijų ir projektų vadyba. Akademija: ASU leidybos centras. ISBN: 978-9955-896-88-3.

Saint-Paul, G. (2004). Why Are European Countries Diverging in Their Unemployment Experience? Journal of Economic Perspectives, 18(4), 49-68. https://doi.org/10.1257/0895330042632672

Schramm, L. L. (2017). Technological innovation. Germany: Walter de Gryuter GmbH. ISBN 10: 3110438275.

Schumpeter, J. A. (2008). Capitalism, socialism and democracy, 3rd ed. New York: HarperCollins. ISBN: 978-0-06-156161-0.

Schumpeter, J. A. (2017). The theory of economic development. New York: Routledge. https://doi.org/10.43 24/9781315135564

Separovic, A. (2009). The Influence of the Tax Wedge on Unemployment in OECD Countries in Comparison with Croatia. Financial Theory and Practice, 33(4), 449-463. Available from internet: https://hrcak.srce.hr/48610.

Simonetti, R., Taylor, K., \& Vivarelli, M. (2000). Modelling the employment impact of innovation. In M. Pianta, M. Vivarelli (Eds.), the employment impact of innovation: Evidence and policy (pp. 26-43). London and New York: Routledge. ISBN: 0-415-20433-X.

Strat, V. A., Davidescu (Alexandru), A., \& Paul (Vass), A. M. (2015). FDI and the Unemployment - a Causality Analysis for the Lastest EU Members. Procedia Economics and Finance, 23(2015), 635-643. https://doi.org/10.1016/S22125671(15)00448-7

Tancioni, M., \& Simonetti, R. (2002). A Macroeconometric Model for the Analysis of the Impact of Technological Change and Trade on Employment. Journal of Interdisciplinary Economics, 13(1-3), 185-221. https://doi.org/10.11 77/02601079X02001300109

Van Reenen, J. (1997). Employment and Technological Innovation: Evidence from U.K. Manufacturing Firms. Journal of Labour Economics, 15(2), 255-284. ISSN: 0734-306X.

Visser, J. (2019). ICTWSS Database. Version 6.0. Amsterdam: Amsterdam Institute for Advanced Labour Studies (AIAS), University of Amsterdam. Available from internet: http://uva-aias.net/en/ictwss.

Vivarelli, M. (1995). The economics of technology and employment: Theory and empirical evidence. Aldershot: Elgar. ISBN: 9781858981666.

Vivarelli, M. (2011). Innovation, Employment and Skills in Advanced and Developing Countries: A Survey of the Literature. Inter-American Development Bank Technical Notes No. IDB-TN-351.

Vivarelli, M. (2014). Innovation, Employment and Skills in Advanced and Developing Countries: A Survey of Economic Literature. Journal of Economic Issues, 48(1), 123-154. https://doi.org/10.2753/JEI0021-3624480106

\section{Authors's biographies}

Zigmas Lydeka is a professor, habilitate doctor of social sciences in economics, Emeritus Rector of Vytautas Magnus University. He takes part in the process of doctoral studies in four Lithuanian universities (a member of public defence boards, a supervisor of PhD students, and a teacher of a course of Scientific Methodology). His main scientific interests are economic philosophy, system transformation methodology, entrepreneurship theory and practice, strategic management, firm reorganization, and welfare economy.

Akvilė Karaliūtė is a doctor of social sciences in economics, a lecturer at the Faculty of Economics and Management of Vytautas Magnus University and a junior researcher at the Faculty of Bioeconomy Development of Vytautas Magnus University. She is a committee member in the Economics study program. Her main scientific interests include innovation economics, labour economics, behavioral economics, and econometrics.

The article has been reviewed.

Received in October 2019; accepted in April 2021.

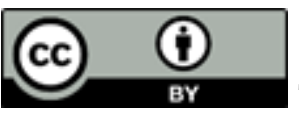

This article is an Open Access article distributed under the terms and conditions of the Creative Commons Attribution 4.0 (CC BY 4.0) License (http://creativecommons.org/licenses/by/4.0/). 